\title{
Brilliant but unrealistic?
}

\section{Washington}

THE Strategic Defense Initiative (SDI) takes on a new shape in the defence budget proposals released by the White House last week. Instead of the elaborate system of large interceptor rockets and sophisticated sensor platforms envisaged under the Reagan administration, centre stage is taken by an orbiting swarm of thousands of cheap and simple 'brilliant pebble' interceptor rockets.

Each three-foot-long 'pebble' is guided by an optical sensor linked to a computer and is designed to destroy independently ballistic missiles in their boost phase by slamming into them at high speed.

Presidential backing for brilliant pebbles comes after a year of vigorous lobbying by Edward Teller, former director of the Lawrence Livermore Laboratory and physicist Lowell Wood, director of advanced studies at the same institute. But critics say there is no reason to believe the untried concept is anything more than an intriguing idea. "The current political fad for brilliant pebbles is more a testament to the triumph of hope over reality, political salesmanship and access, and the desperation of SDI programme managers to deploy something sooner rather than later, than it is to any engineering breakthrough", says John Pike, a space policy analyst for the Washington-based Federation of American Scientists.

A key attraction is that the scheme saves money. By concentrating on brilliant pebbles and delaying some other parts of the SDI programme, US President George Bush is able to cut his predecessor's 1990 SDI budget request from
$\$ 5,600$ million to $\$ 4,500$ million, only a small increase over the amount finally agreed with Congress last year. And much bigger savings may be on the way, according to a report released from outgoing SDI director, Lt General James Abrahamson in February. He claims brilliant pebbles could help halve SDI's estimated costs.

Such considerations weigh heavily as Bush proposes cancelling several military programmes and slowing the development of others, including the B2 Stealth bomber, in order to reduce the defence budget by $\$ 10$ thousand million dollars. But Pike points out that "the iron law of aerospace engineering is that everything always looks quick and cheap and simple until you actually start working on it".

Each pebble carries its own sensor and sophisticated computer. Optical sensors are favoured over the infra-red sensors planned for other space-based interceptors because they are cheap and do not require cryogenic cooling. But they may not be efficient. Brilliant pebbles' biggest strength lies in their numbers. As many as 10,000 might be deployed in space making them far less vulnerable to attack than orbiting 'garages' of interceptors. And as each pebble carries its own sensor and could carry out an independent attack there would be less need to worry about some of the complicated control and communications problems that bedevilled earlier versions of SDI. But independent action carries the risk that, once activated, the pebbles would not be brilliant enough to tell friend from foe and would be as likely to shoot down the Space Shuttle as a Soviet rocket.

Alun Anderson

\section{University bombed}

Munich

UNKNOWN sympathizers of the terrorist organization RAF (Rote Armee Fraktion) placed firebombs in a hallway of the mathematics institute of the Technical University of Berlin last week, causing several hundred thousand deutsche marks' worth of damage. Police are still searching for the attackers, who spray-painted a message on the wall of the institute expressing support for RAF terrorists held in solitary confinement who had been carrying out a twomonth hunger strike.

University Chancellor Ulrich Podewils said that it was not clear why the university was chosen as a target.

S.D.

\section{No museum piece \\ Munich}

CAREER politician Erhard Busek replaced biochemist Hans Tuppy as Science Minister in Austria on 24 April. Busek, 48, has a doctorate in law but has made a name for himself in cultural affairs as deputy mayor of Vienna. Busek, like Tuppy, was nominated by the conservative People's Party (Volkspartei).

In an interview on Austrian television on 24 April, Busek said that he supports his predecessor's goal of investing 1.5 per cent of Austria's gross domestic product in science and technology by 1990 . "If we don't do something soon," said Busek, "then Austria will not just have a lot of museums. We will be a museum." S.D.

\section{Chernobyl censorship}

\section{London}

SOVIET film-maker Nikolai Mashenko, whose film on the Chernobyl catastrophe was released last October, has made a formal complaint to the Soviet government about the censorship of this work. Whole sequences, he said, were cut at the insistence of the Soviet Ministry of Health and Ministry of Atomic Energy. His complaint was filed several weeks ago, but so far he has received no answer.

V.R.

\section{Tokyo}

JAPAN last month hosted a United Nations meeting on disarmament in Kyoto. The meeting, proposed last June by Prime Minister Noboru Takeshita, is the first of its kind to be held in Japan and is indicative of Japan's growing involvement in world affairs. No disarmament agreements were reached - the meeting was intended to be a forum for 'open and frank' discussion - but moves were made towards the establishment of a global seismic network to monitor small underground nuclear explosions.

The Kyoto conference, attended by representatives of 31 countries, covered several aspects of disarmament, including non-proliferation of nuclear, chemical and other weapons, confidence-building measures and nuclear test-ban verification. But particular emphasis was placed on test-ban verification because this is an area to which Japan can contribute through its expertise in seismology.

Before the conference, scientists attending the meeting saw a demonstration of the exchange of data between Australia and Japan at the Meteorological Agency in Tokyo. Seismologists reported at the working group session on test-ban verification that a global network of 50 seismic stations could detect nuclear blasts as small as one kiloton, and agreements were made among the participants for further exchange of data as a step towards establishing such a network

The US Pentagon opposes a comprehensive test-ban treaty, insisting that tests are essential for development and modernization of weapons. But a global seismic network could allow a 'step-by-step' reduction in the scale of nuclear tests, as proposed by Japan at the 1984 Geneva Conference.
David Swinbanks

\section{Danish merger}

\section{London}

DENMARK's two largest pharmaceutical companies are to proceed with their planned merger, following shareholder approval last week. Novo-Nordisk, the outcome of the merger between Novo Industri and Nordisk Gentofte, will combine their research on the production of hormones and other polypeptides by recombinant DNA techniques.

The new company will supply close to half of the world's demand for insulin, and continue Novo's position as the largest supplier of industrial enzymes. It will also be increasingly involved in diagnostics, not least as a result of Novo's recent acquisition of two UK companies, IQ (Bio) and Celltech Diagnostics. 